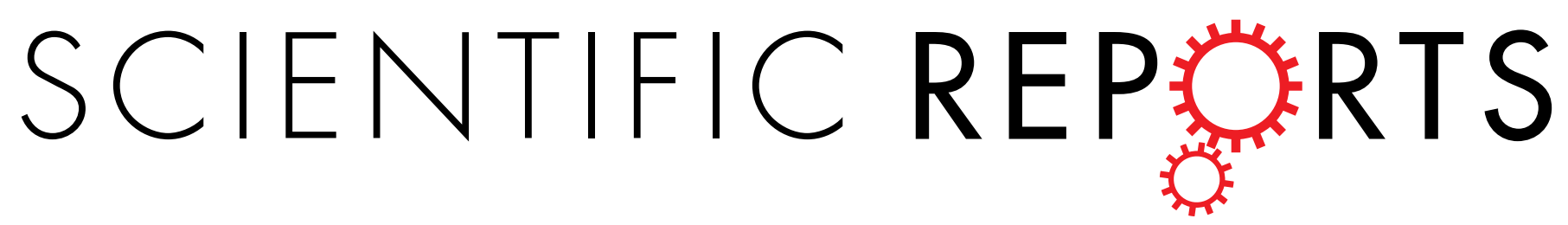

\title{
OPEN
}

\section{Author Correction: N-Alkylation of functionalized amines with alcohols using a copper-gold mixed photocatalytic system}

Lyu-Ming Wang ${ }^{1}$, Yuna Morioka ${ }^{1}$, Kellie Jenkinson ${ }^{2}$, Andrew E. H. Wheatley ${ }^{2}$, Susumu Saito ${ }^{1}{ }^{1}$ \& Hiroshi Naka $\mathbb{D}^{1}$

Correction to: Scientific Reports https://doi.org/10.1038/s41598-018-25293-z, published online 02 May 2018

In Figure 4c, there is an error in the wavy line of the product structure as it was wrongly disconnected from the amine group. The correct Figure 4 appears below as Figure 1.

${ }^{1}$ Graduate School of Science and Research Center for Materials Science, Nagoya University, Chikusa, Nagoya, 464-8602, Japan. ${ }^{2}$ Department of Chemistry, University of Cambridge, Lensfield Road, Cambridge, CB2 1EW, UK. Correspondence and requests for materials should be addressed to A.E.H.W. (email: aehw2@cam.ac.uk) or S.S. (email: saito.susumu@f.mbox.nagoya-u.ac.jp) or H.N. (email: h_naka@nagoya-u.jp) 
a<smiles>[R7]OC(=O)CC(C)C(C)c1ccccc1</smiles>

$1 b$

3<smiles>CC(C)OCCN(C)C(C)c1ccccc1</smiles>

3bd, $75 \%$<smiles>CCN(C[Ga]Cl)C(C)c1ccccc1</smiles>

3be, $67 \%{ }^{\dagger}$

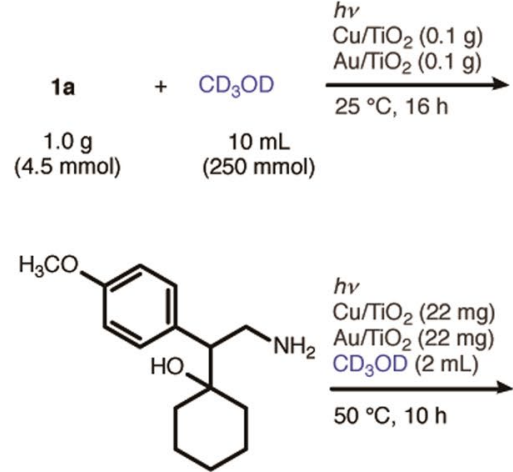

(0.2 mmol)<smiles>CCN(C)C(=O)Oc1cccc(C(C)N(C(=O)O[Na])C(C)(C)C)c1</smiles>

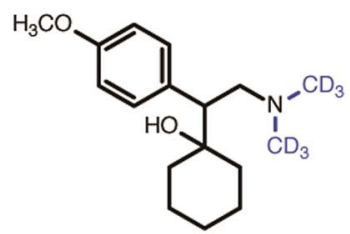

Venlafaxine- $d_{6}\left(3 \mathrm{ja}-d_{6}\right)$ $72 \%$ (> 95\%D)<smiles>C[NH2+]CCCN1c2ccccc2CCc2ccccc21</smiles>
$\mathrm{Cu} / \mathrm{TiO}_{2}(22 \mathrm{mg})$ $\mathrm{Au} / \mathrm{TiO}(22 \mathrm{mg}$ $\mathrm{CD}_{3} \mathrm{OD}(2 \mathrm{~mL})$ $25^{\circ} \mathrm{C}, 5 \mathrm{~h}$; $\mathrm{Na}_{2} \mathrm{CO}_{3} \mathrm{aq}$

$(0.2 \mathrm{mmol})$<smiles>CN(CCCN1c2ccccc2CCc2ccccc21)C(=O)O</smiles>

Imipramine- $d_{3}\left(8-d_{3}\right)$ $94 \%(>95 \% \mathrm{D})$

c

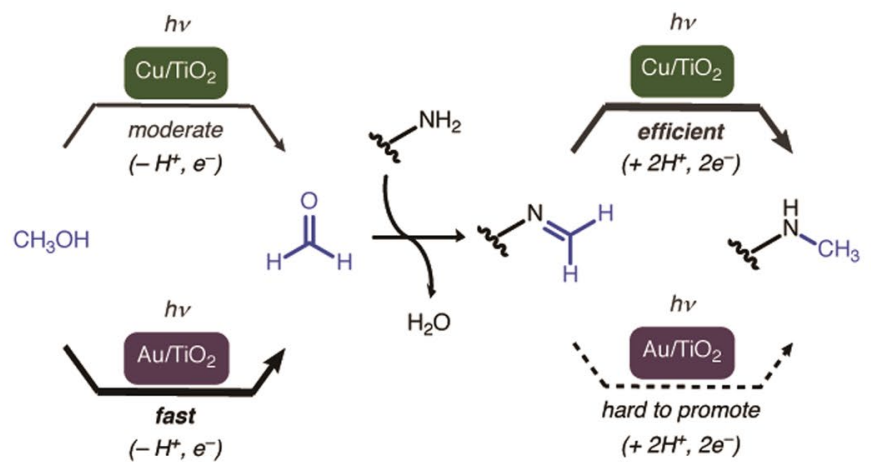

Figure 1. N-Alkylation of Amines by the $\mathrm{Cu}-\mathrm{Au}$ mixed photocatalytic system. (a) Non-symmetrical N,Ndialkylation. Reaction conditions: * $\mathbf{1 b}(1.0 \mathrm{mmol}), \mathrm{Cu} / \mathrm{TiO}_{2}(22 \mathrm{mg}), \mathrm{Au} / \mathrm{TiO}_{2}(22 \mathrm{mg})$, triethylene glycol monomethyl ether (2 equiv), $\mathrm{CPME}(10 \mathrm{~mL}), h v, \mathrm{Ar}, 50^{\circ} \mathrm{C}, 13 \mathrm{~h}$; $\mathrm{CH} 3 \mathrm{OH}(5 \mathrm{~mL}), 50^{\circ} \mathrm{C}, 6 \mathrm{~h} .{ }^{\dagger} \mathbf{1 b}(1.0 \mathrm{mmol}), \mathrm{Cu} /$ $\mathrm{TiO}_{2}$ (22 mg), $\mathrm{Au} / \mathrm{TiO}_{2}(22 \mathrm{mg}), 8$-chloro-1-octanol (2 equiv), CPME (10 mL), $h v, \mathrm{Ar}, 25^{\circ} \mathrm{C}, 16 \mathrm{~h} ; \mathrm{C} 2 \mathrm{H} 5 \mathrm{OH}(5 \mathrm{~mL})$, $25^{\circ} \mathrm{C}, 16 \mathrm{~h}$. (b) Synthesis of deuterated drugs. (c) Synergistic effect in the $\mathrm{Cu}-\mathrm{Au}$ mixed photocatalytic system. 
Open Access This article is licensed under a Creative Commons Attribution 4.0 International License, which permits use, sharing, adaptation, distribution and reproduction in any medium or format, as long as you give appropriate credit to the original author(s) and the source, provide a link to the Creative Commons license, and indicate if changes were made. The images or other third party material in this article are included in the article's Creative Commons license, unless indicated otherwise in a credit line to the material. If material is not included in the article's Creative Commons license and your intended use is not permitted by statutory regulation or exceeds the permitted use, you will need to obtain permission directly from the copyright holder. To view a copy of this license, visit http://creativecommons.org/licenses/by/4.0/.

(c) The Author(s) 2018 